\title{
A Study on the Influence of the Business Talent Training Model of Universities in Guangdong, Hong Kong, and Macao on the Employment of Students*
}

\author{
Yanyu Li \\ School of Business \\ Beijing Institute of Technology, Zhuhai \\ Zhuhai, China
}

\author{
Jiahao Chang \\ School of Business \\ Beijing Institute of Technology, Zhuhai \\ Zhuhai, China \\ Chih Huang** \\ School of Business \\ Beijing Institute of Technology, Zhuhai \\ Zhuhai, China \\ **Corresponding Author
}

\author{
Jinwei Wang \\ School of Business \\ Beijing Institute of Technology, Zhuhai \\ Zhuhai, China \\ $\mathrm{Li} \mathrm{Xu}$ \\ School of Business \\ Beijing Institute of Technology, Zhuhai \\ Zhuhai, China
}

\begin{abstract}
This study is about the influence of the business talent training model in Guangdong, Hong Kong, and Macao universities on the employment of students, and the research is carried out through interviews and questionnaires. The results of the study show that: (1) most business students in Guangdong, Hong Kong, and Macao universities plan to take up employment after graduation. From a regional perspective, students in Hong Kong are most likely to choose to work after graduation. (2) Compared with students in Guangdong, students in Hong Kong and Macau think that recommending to companies, publishing job consultations, and offering employment guidance courses are more helpful for them. (3) In the three activities of teacher recommendation, corporate internship, and campus recruitment meeting, there are significant differences between students in Guangdong, Hong Kong, and Macao.
\end{abstract}

Keywords-Guangdong, Hong Kong, and Macao universities; talent training model; employment

\section{INTRODUCTION}

China's "13th Five-Year Plan" proposes to deepen the cooperation of the Mainland with Hong Kong and Macao and implement the strategy of talent development. The completion of the Hong Kong-Zhuhai-Macao Bridge has made the economic and trade development of the Guangdong-Hong Kong-Macao Greater Bay Area more integrated and extensible, and the exchanges between Guangdong, Hong Kong and

*This article is one of the phased achievements of the 2017 Undergraduate Innovation and Entrepreneurship Training Program of Beijing Institute of Technology, Zhuhai (project code: 3500002/021/005/018).
Macau have become more convenient and closer. More and more talents from Hong Kong and Macao have come to the Mainland to work, which is both an opportunity and a challenge for the talent market in Guangdong. The employment competition in the three areas has become increasingly fierce, and the demand for labor has shifted from quantity to quality, putting forward higher requirements on talent training. Since the economic development of the Bay Area is becoming more and more important, the competitiveness of business talents themselves has become particularly important, and schools play an important role in cultivating competitive business talents. As the market's demand for commercial talents has undergone major changes, the model for cultivating business talents must be more diversified and internationalized in order to cultivate talents needed by the market. Therefore, this study focuses on the business personnel training model of universities in Guangdong, Hong Kong, and Macao, and focuses on the impact of the model on students' employment, hoping to conduct field research on business personnel training models in different universities in the three areas, and to propose reference suggestions on the existing problems. The overall model for the cultivation of business talents in colleges and universities in Guangdong, Hong Kong, and Macao has been summarized and it can effectively improve the competitiveness of students in the job market. 


\section{LITERATURE REVIEW}

\section{A. Talent Cultivation Mode}

The talent cultivation model is one of the most varied and most dynamic subsystems in the "talent cultivation" system, and it is also the subsystem with the most complex constituent elements. The change of the talent cultivation model is essentially the change of its constituent elements; the innovation of the talent cultivation model is also mainly the innovation or reorganization of its various constituent elements. The business personnel training model includes talent cultivation concept, speciality setting mode, curriculum setting method, teaching system, teaching organization form, teaching management model, and invisible course form. Therefore, the operation of the system includes the establishment of concepts, speciality setting, curriculum setting, and the construction of the teaching system, indicating that talent cultivation is based on the effective convergence and combination of the elements in the system. In this study, it is believed that in order to cultivate commercial talents in universities, the system must be organized in this way. In addition to making students have a solid theoretical basis, schools and employment guidance departments should use more diversified and more systematic ways to improve students' practical employment skills in the teaching practice.

\section{B. The Impact of Colleges and Universities on Student Employment}

Li Zhiliang (2018) once suggested that schools were important sites for cultivating and shaping talents. Colleges and universities should provide guidance and services for students to help them cultivate and accumulate professional abilities, so that they can meet the market's demand for various professional talents, and improve the probability of successful employment of the graduates. In other words, the employment guidance of colleges and universities should be targeted, and the school and the in-school employment guidance department should analyze the reasons for the employment difficulties of graduates, provide guidance according to specific conditions, and fully play the role of the school employment and entrepreneurship service center. In addition, whether the school can fully play the role of school-enterprise cooperation and carry out various employment-related activities also has an important impact on student employment. For example, organizing campus job fairs and inviting companies to conduct employment guidance, career planning lectures, or vocational skill training in universities can enable students to truly understand the company' $s$ talent standards and improve their professional abilities.

Zhang Rui (2011) believes that the problems in current employment guidance for university graduates in China are simplex and scattered content of employment guidance, lack of innovation in employment guidance courses, non-professional employment guidance team, and formalized career planning work. Based on the economic characteristics of Guangdong, Hong Kong, and Macao and their ardent demand for business talents, how to collect talent demand information in the employment market through schools and employment guidance departments in universities is extremely important for training business talents, setting up employment guidance systems, setting up innovative courses and activities in line with international standards, and assisting business students in the successful employment in the Guangdong, Hong Kong and Macau talent markets. Therefore, it is important and necessary to discuss the influence of college business personnel training model on student employment.

\section{RESEARCH METHODS}

This study was conducted in two phases. First, interviews were conducted with 12 teachers from 11 universities and colleges in Guangdong, Hong Kong, and Macau, to make us get a preliminary understanding of their focus on the cultivation of business students and the student employment activities. A preliminary draft of the survey questionnaire was developed based on the content of the interviews and the literature research. Through the pre-test (30 samples), according to the opinions of the subjects on the semantics of the questions and the completeness of the questionnaire, the preliminary draft was revised to form the formal questionnaire. At the second stage, the questionnaires were sent to the subjects and filled in. The questionnaires were sent through WeChat, QQ and in the field. A total of 301 questionnaires were retrieved. Apart from the invalid samples, there are 256 valid samples and the valid recovery rate is $85.05 \%$. Respondents are all university business students, of whom $52.73 \%$ are from Guangdong, $19.53 \%$ are from Hong Kong, and $27.73 \%$ are from Macau.

\section{ANALYSIS RESULTS}

\section{A. What to Do after Graduation}

From "Table I", it can be seen that most of the students from universities in Guangdong, Hong Kong, and Macao choose to work after graduation (55.5\%), followed by taking part in the entrance exams for postgraduate schools (25.8\%). From a regional point of view, Hong Kong students have the highest intention of going to work after graduation, reaching $78.0 \%$, followed by that of Guangdong students (66.7\%); while Macao students choose to take part in the entrance exams for postgraduate schools $(47.9 \%)$ more than choose employment $(18.3 \%)$.

TABLE I. CROSS-TAB ANALySIS OF REGIONS AND PLANNED DIRECTIONS OF STUDENTS AFTER GRADUATION

\begin{tabular}{lccccc}
\hline \multirow{2}{*}{ Regions } & \multicolumn{5}{c}{ Planned Directions after Graduation } \\
\cline { 2 - 6 } & Work & $\begin{array}{c}\text { Postgrad } \\
\text { uate }\end{array}$ & $\begin{array}{c}\text { Study } \\
\text { abroad }\end{array}$ & Pioneer & Others \\
\hline $\begin{array}{l}\text { Guangdo } \\
\text { ng }\end{array}$ & $66.7 \%$ & $22.2 \%$ & $5.9 \%$ & $4.4 \%$ & $0.7 \%$ \\
Hong & $78.0 \%$ & $4.0 \%$ & $8.0 \%$ & $10.0 \%$ & - \\
Kong & $18.3 \%$ & $47.9 \%$ & $29.6 \%$ & $2.8 \%$ & $1.4 \%$ \\
Macao & $18.3 \%$ & $25.8 \%$ & $12.9 \%$ & $5.1 \%$ & $0.8 \%$ \\
\hline Total & $55.5 \%$ & & & \\
\hline
\end{tabular}

B. Activities Organized by the School Employment Guidance Department

From the cross-sectional analysis in "Table II", it can be seen that among the activities organized by the school employment guidance department, the business students in 
Guangdong, Hong Kong, and Macao attach great importance to the three activities of recommending to enterprises, issuing job consultations, and setting up employment guidance courses. Business students in Hong Kong and Macau attach greater importance to these activities than students in Guangdong. $62.0 \%$ of Hong Kong students and $70.4 \%$ of Macao students think that employment guidance courses should be set up, while only $31.1 \%$ of Guangdong students think that such courses should be provided. Secondly, $76 \%$ of Hong Kong students and $76.1 \%$ of Macau students think that recommending to enterprises is important, while only $51.9 \%$ of Guangdong students consider it important. $72 \%$ of Hong Kong students and $73.2 \%$ of Macau students think it necessary to post job consultations, and only $52.6 \%$ of Guangdong students think it is necessary.
TABLE II. CROSS-TAB ANALYSIS OF STUDENTS FROM GUANGDONG, HONG KONG, AND MACAO AND ACTIVITIES ORGANIZED BY IN-SCHOOL EMPLOYMENT GUIDANCE DEPARTMENTS (UNIT: PERSON-TIMES)

\begin{tabular}{|c|c|c|c|}
\hline \multirow{2}{*}{ School Activities } & \multicolumn{3}{|c|}{ Regions } \\
\hline & Guangdong & Hong Kong & Macao \\
\hline Recommend to businesses & $51.9 \%$ & $76.0 \%$ & $76.1 \%$ \\
\hline $\begin{array}{l}\text { Hold employment } \\
\text { competitions }\end{array}$ & $26.7 \%$ & $28.0 \%$ & $36.6 \%$ \\
\hline Post job information & $52.6 \%$ & $72.0 \%$ & $73.2 \%$ \\
\hline Resume design guide & $35.6 \%$ & $58.0 \%$ & $63.4 \%$ \\
\hline Hold mock job fairs & $44.4 \%$ & $48.0 \%$ & $63.4 \%$ \\
\hline $\begin{array}{l}\text { Set up employment instruction } \\
\text { courses }\end{array}$ & $31.1 \%$ & $62.0 \%$ & $70.4 \%$ \\
\hline $\begin{array}{l}\text { Hold employment guidance } \\
\text { seminars }\end{array}$ & $17.8 \%$ & $40.0 \%$ & $56.3 \%$ \\
\hline $\begin{array}{l}\text { Keep track of students after } \\
\text { employment }\end{array}$ & $17.0 \%$ & $38.0 \%$ & $59.2 \%$ \\
\hline
\end{tabular}

\section{Employment Activities Held by Schools}

"Table III" shows that students from Guangdong, Hong Kong, and Macao have different opinions on activities that are held by schools and helpful to the employment of business students, such as teacher recommendations $(\mathrm{F}=5.321, \mathrm{p}<0.01)$, corporate internships $(\mathrm{F}=11.748, \mathrm{p}<0.001)$, and campus job fairs $(\mathrm{F}=3.556, \mathrm{p}<0.05)$. From the Scheffe's multiple comparison analysis of this study, it can be found that Hong Kong and Macau students think teacher recommendations more helpful to employment than Guangdong students. Secondly, students in Hong Kong and Macau think corporate internships more helpful than students in Guangdong. Similarly, for campus job fairs, students in Hong Kong and Macau have higher degrees of recognition for them than students in Guangdong.

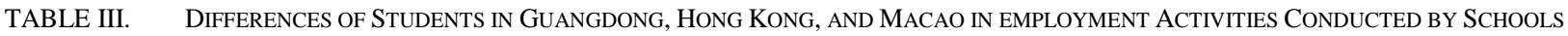

\begin{tabular}{|c|c|c|c|c|c|c|}
\hline Dimensions & Regions & $\mathbf{M}$ & SD & F value & $P$ value & Scheffe's Multiple Comparisons \\
\hline \multirow{3}{*}{ Teacher recommendations } & (1) Guangdong & 3.73 & 0.696 & \multirow{3}{*}{$5.321 * *$} & \multirow{3}{*}{0.005} & \multirow{3}{*}{$\begin{array}{l}(2)>(1) \\
(3)>(1)\end{array}$} \\
\hline & (2) Hong Kong & 4.10 & 0.789 & & & \\
\hline & (3) Macao & 3.96 & 0.818 & & & \\
\hline \multirow{3}{*}{ Business visit } & (1) Guangdong & 3.87 & 0.786 & \multirow{3}{*}{1.512} & \multirow{3}{*}{0.223} & \multirow{3}{*}{-} \\
\hline & (2) Hong Kong & 3.78 & 0.910 & & & \\
\hline & (3 Macao & 4.09 & 0.774 & & & \\
\hline \multirow{3}{*}{ Corporate internships } & (1) Guangdong & 4.08 & 0.692 & \multirow{3}{*}{$11.748 * * *$} & \multirow{3}{*}{0.000} & \multirow{3}{*}{$\begin{array}{l}(2)>(1) \\
(3)>(1)\end{array}$} \\
\hline & (2) Hong Kong & 4.46 & 0.788 & & & \\
\hline & (3) Macao & 4.55 & 0.713 & & & \\
\hline \multirow{3}{*}{ Campus job fairs } & (1)Guangdong & 3.83 & 0.686 & \multirow{3}{*}{$3.556^{*}$} & \multirow{3}{*}{0.030} & \multirow{3}{*}{$\begin{array}{l}(2)>(1) \\
(3)>(1)\end{array}$} \\
\hline & (2)Hong Kong & 4.00 & 0.881 & & & \\
\hline & (3)Macao & 4.11 & 0.747 & & & \\
\hline \multirow{3}{*}{$\begin{array}{l}\text { In-school employment guidance } \\
\text { department }\end{array}$} & (1)Guangdong & 3.73 & 0.737 & \multirow{3}{*}{1.989} & \multirow{3}{*}{0.139} & \multirow{3}{*}{-} \\
\hline & (2)Hong Kong & 3.72 & 0.784 & & & \\
\hline & (3)Macao & 3.93 & 0.704 & & & \\
\hline \multirow{3}{*}{$\begin{array}{l}\text { Enterprises' specific recruitment of } \\
\text { a college/speciality }\end{array}$} & (1)Guangdong & 3.73 & 0.777 & \multirow{3}{*}{2.019} & \multirow{3}{*}{0.135} & \multirow{3}{*}{-} \\
\hline & (2)Hong Kong & 3.72 & 0.701 & & & \\
\hline & (3)Macao & 3.94 & 0.843 & & & \\
\hline
\end{tabular}

The above data reflects that colleges and universities in Guangdong need to strengthen or adjust the employment guidance activities in order to increase students' attention and recognition of the activities. Universities in Guangdong should learn from universities in Hong Kong and Macau, and strive to provide more effective employment guidance and assistance for business students in Guangdong.

\section{CONCLUSION}

\section{A. Conclusions}

Based on the findings of this study, the following conclusions are summarized:

- Most of business students in Guangdong, Hong Kong, and Macao universities plan to go to work after graduation, and the number of students in Hong Kong 
who choose to work is the largest. In Macao, there are more students who choose to take graduate schools than that of choosing to work.

- With regard to the activities organized by school employment guidance departments, business students in Guangdong, Hong Kong, and Macao are all quite satisfied with the three activities of recommending to companies, issuing job offers, and offering employment guidance courses. From a regional perspective, business students in Hong Kong and Macau attach greater importance to these activities than business students in Guangdong.

- About the three activities of teacher recommendations, corporate internships, and campus recruitment conferences, the students from Guangdong, Hong Kong, and Macao have different opinions. Students in Hong Kong and Macau recognize these activities more than students from Guangdong.

\section{B. Suggestions}

Based on the conclusions of the study, the following related suggestions are proposed:

1) Strengthen and improve the school-enterprise cooperation mechanism: Recommendations to companies: Hong Kong and Macau have strong business climate, longterm development of the market economy system, perfect economic systems, and mature cooperation mechanisms between enterprises and universities, enabling Hong Kong and Macao college students to actively participate in the school-recommended companies and to promote the development of their own careers. Guangdong should perfect the school-enterprise cooperation mechanism. While extensively conducting campus recruiting, companies can cooperate with the schools' employment guidance departments, organize lower-grade students to take part in summer business internships, and organize the direct contract work with graduates.

2) Improve the professionalism of the school employment guidance center: Enterprises in Hong Kong and Macao have mature establishment, supervision and development systems, and the relevant business information of enterprises is open and transparent. In terms of employment channels for graduates, in addition to social channels, the school's employment guidance center will also actively seek suitable enterprises and posts for graduates. Stringent labor contract laws and a complete recruitment information environment make it easier for students in Hong Kong and Macau to obtain job counseling. The employment guidance centers in universities and colleges in Guangdong need to enhance the examination of companies' operating capabilities and the understanding of the employment needs of companies. Strictly screen the companies and recommend appropriate companies to students. At the same time, guide students to actively participate in and browse the employment information platform in the school, so that students can enjoy employment security and find companies and positions that match their abilities when entering the job market.

3) Improve the quality of teachers: In addition to recruiting outstanding teachers with academic abilities, Guangdong universities also need to introduce practical teachers who own work experiences in enterprises or international backgrounds. Colleges and universities should double-educate students, not only cultivating students' academic abilities, but also strengthening students' practical work abilities. Teachers should guide students to actively find suitable jobs, and recommend outstanding students to enterprises that they approve, so that students can become excellent college graduates with complete knowledge.

\section{REFERENCES}

[1] Z. F. Dong. "On the Concept and Constitution of University's Cultivating Pattern", The road to success,2015, vol. 15:pp.30-36.

[2] Z. L. Li. "The Strategy of Employment Helping for College Students",Literature Education, 2018, 04: pp. 152-153.

[3] R. Zhang. "Research on the Status and Countermeasures of Career Guidance to Chinese College Students",Journal of Huaihai Institute of Technology, 2011, vol. 09, pp.130-132. 